\title{
HUBUNGAN KEBIJAKAN KRIMINAL DENGAN KEBIJAKAN HUKUM PIDANA
}

\author{
Oleh: \\ Febriyanti Silaen ${ }^{1)}$ \\ dan Syawal Amry Siregar ${ }^{2)}$ \\ Universitas Darma Agung ${ }^{1,2)}$ \\ E-mail: \\ silaen85felixagnes@gmail.com ${ }^{1)}$ \\ dan syawalsiregar59@gmail.com ${ }^{2)}$
}

\begin{abstract}
The problem of overcoming crime in the community cannot be separated from the word Criminal policy which is carried out in the efforts of criminal policy and political policy. The relationship of criminal policy with criminal law policy is equally tackling crime where one is, by means of a penal effort while the difference is with non-criminal words or with the enforcement system only, if the criminal policy uses the word criminal justice system, with some crime prevention and handling by means of Penalty has several stages: Formulation (Legislative Policy), Application (Judicial or Judicial Policy); Execution (Executive Policy). Criminal countermeasure policy is the same as criminal law policy, which is protecting society to achieve social welfare. The effectiveness of criminal sanctions can be an important aspect to support the achievement of the criminal policy.
\end{abstract}

Keywords: Criminal Policy, Political Policy, Formulation (Legislative Policy), Application (Judicial or Judicial Policy), Execution (Executive Policy)

\begin{abstract}
ABSTRAK
Masalah penanggulangan kejahatan dimasyarakat tidak dapat dipisahkan dari kata kebijakan. Kriminal yang dilakukan upaya kebijakan penal dan politik hukum pidana. Hubungan kebijakan Kriminal dengan kebijakan hukum pidana sama-sama menanggulangi kejahatan dimana satu, dengan cara upaya penal sedangkan perbedaanya dengan kata-kata non penal atau dengan sistem penegakan saja, kalau kebijakan kriminal memakai kata sistem peradilan pidana, dengan beberapa Pencegahan dan penanggulangan kejahatan dengan sarana penal memiliki beberapa tahap: Formulasi (Kebijakan Legislatif), Aplikasi (Kebijakan Yudikatif atau peradilan); Eksekusi (Kebijakan Eksekutif). Kebijakan penanggulangan criminal sama dengan kebijakan hukum pidana yaitu melindungi masyarakat untuk mencapai kesejahteraan sosial. Efektifitas sanksi kejahatan bisa menjadi aspek penting untuk mendukung tercapainya kebijakan kriminal tersebut.

Kata Kunci: Kebijakan Kriminal, Kebijakan Politik, Formulasi (Kebijakan Legislatif), Aplikasi (Kebijakan Yudikatif atau peradilan), Eksekusi (Kebijakan Eksekutif)
\end{abstract}




\section{PENDAHULUAN}

Perbuatan yang diusahakan untuk dicegah atau ditanggulangi dengan hukum pidana harus merupakan perbuatan yang tidak dikehendaki, yaitu perbuatan yang mendatangkan kerugian (material dan atau spiritual) atas warga masyarakat.

Penggunaan hukum pidana harus pula memperhitungkan prinsip biaya dan hasil (cost and benefit principle),hukum pidana harus pula memperhatikan kapasitas atau kemampuan daya kerja dari badanbadan penegak hukum yaitu jangan sampai ada kelampauan beban tugas (overvelasting).

KUHAP dan UU Kekuasaan Kehakiman itu memuat asas-asas yang harus diwujudkan dalam penyelenggaraan acara pidana, khususnya oleh jajaran aparat penegak hukum (official criminal justice system). Asas-asas dimaksud antara lain:

1. Peradilan cepat, sederhana, dan biaya ringan

2. Presumption innocence(Praduga tak bersalah)

3. Oportunitas

4. Pemeriksaan terbuka untuk umum

5. Semua orang diperlakukan sama di depan hakim

6. Tersangka/terdakwa berhak mendapatkan bantuan hukum

7. Akusatoir dan

8. Pemeriksaan oleh hakim secara langsung dan lisan.

Penanggulangan kejahatan dengan hukum pidana terutama masalah delik beragama memerlukan politik hukum kriminal yakni kepentingan amsyarakat dan terjamin oleh Negara. Perbuatan yang berkenaan dengan permusuhan, kebencian atau penghinaan permusuhan, penodaan agama, menganjurkan atau mengusahakan dukungan umum untuk pencafsiran agama, merupakan delik-delik agama pada BAB $\mathrm{V}$ tentang Kejahatan terhadap ketertiban umum KUHP karena kejahatan beragama dan harus dilindungi. Bahkan penanganan kasus beragama juga bermacam-macam:

- Ketika campur tangan pemerintah atau polisi berupa tindakan sewenang-wenang selama kegiatan ibadah berlangsung maka saat itulah pelanggaran;

- UU juga menjadi kebijakan diskriminatif bagi golongan minoritas sehingga rumah ibadah dan dituduhkan pelanggaran terhadap kebebasan beribadah;

- Aparat kepolisian wajib melindungi suatu golongan untuk menjalankan ibadah agar tidak diganggu golongan lain, maka polisi dapat dituduh melanggar kebebasan beribadah.

Pandangan tersebut dianggap diskriminatif dan bertenggang rasa yang menimbulkan penolakan atau kebencian atas golongan lain. Ini merupakan bukan kriminal murni seperti mencuri, karena unsur kebencian saja. Maka pada kebijakan penanggulangan kejahatan dengan hukum pidananya, diaturlah upaya kebijakan penal dan non penal.

Kebijakan penal lebih focus kepada upaya represif setelah kejahatan dilakukan, Polisi, Jaksa, dan Hakim memang bertindak sesuai dengan aturan mainnya. Sedangkan upaya non-penal lebih focus kepada pencegahan (preventif). Dan ini kebijakan criminal kepada kebijakan formulasi UU (Pasal Penodaan Agama), aplikasi dan eksekusi.

Hubungan kebijakan kriminal dengan KUHP, Pasal 156, Pasal 156 a KUHP dan UU PNPS No 1 Tahun 1965 
tentang Penodaan Agama memang tidak menanggiulangi delik agama. Sehingga saling berhubungan kebijakan hukum pidana dengan kebijakan kriminal dengan tahap aplikasinya.

Para penegak hukum dalam hal pembangunan hukum untuk menanggulangi delik agama atau yang sering disebut kebijakan criminal. Apalagi berkaitan dengan masalah kriminalisasi dimana penentuan perbuatan yang dijadikan pidana harus melalui tahap-tahap kriteria perbuatan yang tidak dikehendaki karena telah menimbulkan korban.

\section{TINJAUAN PUSTAKA}

Istilah kebijakan dalam tulisan ini diambil dari istilah "policy" (Inggris) atau "politiek" (Belanda). Bertolak dari kedua istilah asing ini, maka istilah "kebijakan hukum pidana" dapat pula disebut dengan istilah "politik hukum pidana". Dalam kepustakaan asing istilah "politik hukum pidana" ini sering dikenal dengan berbagai istilah, antara lain "penal policy", criminal law policy, atau strafrechtspolitiek.

Sudarto menyatakan 3 arti mengenai kebijakan kriminal yaitu:

- Dalam arti sempit, artinya keseluruhan asas dan metode yang menjadi dasar dari reaksi terhadap pelanggaran hukum yang berupa pidana;

- Dalam arti luas, keseluruhan fungsi dari aparatur, penegak hukum termasuk didalannya cara kerja pengadilan dan polisi;

- Dalam arti paling luas, artinya keseluruhan kebijakan yang dilakukan melalui perundangundangan dan badan-badan resmi yang bertujuan untuk menegakan norma-norma sentral dari masyarakat.
Pengertian menurut Marc Ancel, G Peter Hoefnegels, bahwa criminal policy is the rational organixation of the social reaction. Berbagai defenisi yang dikemukakakn Hoefnagels yakni:

1. criminal policy is the science of responses

2. criminal policy is the science of crime prevention

3. criminal policy of designating human behavior as crime

4. criminal policy is the rational of response to crime

upaya penanggulangan kejahatan pada hakikatnya merupakan bagian integral dari upaya perlindungan masyarakat. Oleh karena itu tujuan akhir atau tujuan utama dari politik criminal adalaj perlindungan untuk mencapai kesejahteraan masyarakat. Bagian integral dari politik sosial yaitu kebiajakan atau upaya untuk mencapai kesejahteraan sosial.

Kebijakan kriminal merupakan kebijakan atau penanggulangan kejahatan pada hakikatnya merupakan bagian integral dari upaya perlindungan masyarakat dan upaya mencapai kesejahteraan masyarakat. Oleh karena itu dapat dikatakan bahwa tujuan akhir atau tujuan utama dari politik hukum criminal adalah perlindungan masyarakat untuk mencapai kesejahteraan masyarakat.

Pasal 1 UU Pnps No 1 Tahun 1965:

Setiap orang dilarang dengan sengaja di muka umum menceritakan, menganjurkan atau mengusahakan dukungan umum untuk melakukan penafsiran tentang agama yang dianut di Indonesia atau melakuakn kegiatan-kegiatan keagamaan yang menyerupai kegiatankegiatan keagamaan dari agama 
itu penafsiran dan kegiatan mana menyimpang dari pokok-pokok ajaran agama itu;

Pasal 2 ayat 2:

Barang siapa melanggar ketentuan tersebut dalam pasal 1 diberi perintah dan peringatan keras untuk menghentikan perbuatannya di dalam suatu keputusan bersama Menteri Agama/ Jaksa Agung dan Menteri dalam Negeri.

Pasal 3:

Apabila, setelah dilakukan tindakan oleh Menteri Agama bersama-sama menteri/Jakasa Agung Dan Menteri Dalam Negeri atau oleh Presiden RI menurut ketentuan dalam Pasal 2 terhadap orang, organisasi atau aliran kepercayaan mereka masih melanggar ketentuan dalam Pasal 1 maka orang, penganut anggota dan/atau anggota pengurus organisasi yang bersangkutan dari aliran itu dipidana dengan pidana penjara selama-lamanya 5 tahun.

Berkaitan dengan pasal tersebut perbuatan yang dilarang dalam hukum positif saat ini berupa kebencian, penghinaan permushuan, penyalahgunaan atau penodaan, menganjurkan atau mengusahakan dukungan umum untuk penafsiran agama. Dengan demikian, perbuatan berkenaan kepada ketertiban umum dan bukan penafsiran keagamaan secara pribadi dan wajar ditempatkan pasalpasal berkaitan dengan delik agama Bab $\mathrm{V}$ tentang Kejahatan Ketertiban umum KUHP, dan juga melindungi delik agama itu sendiri.

Kebijakan menanggulangi kejahatan merupakan organisasi rasional dari reaksi-reaksi terhadap kejahatan, juga adalah bagian kebijakan yang lebih luas dalam bidang menegakkan hukum. Hal ini menempatkan hukum perdata dan hukum administrasi menduduki tempat yang sama sebagai sarana pencegah kejahatan yang tidak bersifat pidana, yaitu kebijakan kriminal dapat berwujud baik sebagai pengetahuan maupun sebagai penerapan.

Dua masalah sentral dalam kebijakan kriminal dengan menggunakan sarana penal (hukum pidana) adalah:

1. Perbuatan apa yang seharusnya dijadikan tindak pidana, dan

2. Sanksi apa yang sebaiknya digunakan atau dikenakan kepada si pelanggar.

Kebijakan hukum pidana, termasuk pula kebijakan dalam menangani dua masalah sentral di atas, harus pula dilakukan dengan pendekatan yang berorientasi pada kebijakan (policy oriented approach).

Kebijakan publik dapat menyentuh berbagai aspek berbagai bidang di masyarakat seperti aspek ideology, aspek politik, aspek ekononi, aspek hukum, aspek budaya, aspek sosial yang masing-masing memerlukan kebijakan tersendiri.

Namun demikian lahirnya kebijakan-kebijakan tersebut sebenarnya tidak dapat dilepaskan dan sangat tergantung dari sistem politik suatu negara Silalahi, R (2019). Artinya bila suatu negara hendak membuat suatu kebijakan yang berkaitan dengan aspek kehidupan masyarakat maka perumusan dan penetapan serta pelaksanaannya tidak

dapat terpisah pada sistem politik dari negara yang bersangkutan.

\section{METODE PELAKSANAAN}

Penelitian ini adalah yuridis normatif yakni mengacu kepada normanorma hukum pada peraturan 
perundang-undangan, dan sifatnya adalah deskriptif analitis. Mengacu kepada penelitian yang menggambarkan, menelaah dan menjelaskan secara tepat menganalisis rancangan KUHP dan kebijakan criminal.

Penelitian normatif lebih mendekatkan kepada bahan hukum primer yakni Kitab undang-undang Hukum Pidana, Rancangan KUHP tahun 2003, PNPS Nomor tentang Delik Penodaan Agama.

\section{HASIL dan PEMBAHASAN}

Ada dua masalah sentral dalam kriminal dengan menggunakan sarana penal (hukum pidana) ialah masalah penentuan :

1. Perbuatan apa yang seharusnya dijadikan tindak pidana, dan

2. Sanksi apa yang sebaiknya digunakan atau dikenakan kepada pelanggar.

Kebijakan pidana merupakan teknik peraturan perundang-undangan yang dilakukan secara normatif dan sistematik dogmatik tetapi juga melakukan pendekatan yuridis factual yang berupa sosiologis, historis dan komparatif. Pendekatan komprehensif juga merupakan displin kebijakan sosial.

Penanggulangan kejahatan dapat dilakukan melalui dua pendekatan, yaitu pendekatan penal (penerapan hukum pidana) dan pendekatan non penal (pendekatan di luar hukum pidana).

Politik kriminal (criminal policy) adalah usaha rasional untuk menanggulangi kejahatan. Politik kriminal ini merupakan bagian dari politik penegakan hukum dalam arti luas (law enforcement). Semuanya merupakan bagian dari politik sosial (social policy), yakni usaha dari masyarakat atau negara untuk meningkatkan kesejahteraan warganya.

Namun demikian lahirnya
kebijakan-kebijakan
tersebut
sebenarnya tidak dapat dilepaskan dan
sangat tergantung dari sistem politik
suatu negara.

Artinya bila suatu negara hendak membuat suatu kebijakan yang berkaitan dengan aspek kehidupan masyarakat maka perumusan dan penetapan serta pelaksanaannya tidak dapat terpisah pada sistem politik dari negara yang bersangkutan.

Bentuk yang pertama adalah bersifat represif yang menggunakan sarana penal, yang sering disebut sebagai sistem peradilan pidana (criminal justice system). Dalam hal ini secara luas sebenarnya mencakup pula proses kriminalisasi. Yang kedua berupa usaha-usaha prevention without punishment (tanpa menggunakan sarana penal) dan yang ketiga adalah mendayagunakan usaha-usaha pembentukan opini masyarakat tentang kejahatan dan sosialisasi melalui mass media secara luas.

Subtansi dari kebijakan yang akan dirumuskan, ditetapkan dan dilaksanakan tersebut merupakan kebijakan publik yang nantinya akan digunakan sebagai landasan dan acuan dalam menyelesaikan masalah-masalah yang muncul dalam di masyarakat untuk mencapai tujuan negara yakni kesejahteraan dan perlindungan masyarakat.

Eksistensi penggunaan hukum pidana sebagai sarana menanggulangi kejahatan merupakan bagian integral dari kebijakan perlindungan masyarakat serta merupakan bagian integral politik sosial. Jika politik criminal menggunakan politik hukum pidana maka harus menggunakan sarana penal 
(hukum pidana) tetapi juga menggunakan sarana-sarana non-penal.

Skema social policy dapat dijabarkan sebagai berikut:

1. Pencegahan dan penanggulangan kejahatan yang menunjang tujuan, untuk kesejahteraan perlindungan masyarakat yang bersifat immaterial terutama kepercayaan kebenaran kejjujuran dan keadalan

2. Pencegahan dan penanggulangan kejahatan harus dilakukan pendekatan integral atau keseimbangan penal dan non penal

3. Pencegahan dan penanggulangan dengan sarana penal yang fungsinya berupa tahap formulasi, aplikasi dan eksekutif.

Usaha penanggulangan kejahatan secara penal yang dilakukan melalui langkah-langkah perumusan norma-norma hukum pidana, yang didalamnya mengandung unsur substansi, struktural dan kultur masyarakat tempat sistem hukum tersebut diberlakukan.

Usaha penanggulangan kejahatan melalui sarana penal tersebut dalam sistem peradilan pidana yang didalamnya bergerak secara harmonis dari subsistem pendukungnya yaitu:

1. Kepolisian

2. Kejaksaan

3. Pengadilan

4. Lembaga permasayarakatan

5. KPK

6. Pengacara

Kebijakan sosial atau perlindungan masyarakat mencakup kebijakan hukum pidana materiil, dibidang hukum pidana formil, dan di bidang hukum pelaksaanaan pidana.
Tujuan dibuatnya pedoman politik sosial ini untuk menerapkan undangundang kepada pembuat undang-undang dan penyelenggara dan pelaksana putusan pengadilan.

Pembaharuan hukum pidana merupakan bidang penal policy yang terkait dengan criminal politik. Sebagai suatu kebijakan sosial, pembaruan hukum pidana pada hakikatnya upaya mengatasi masalah-masalah sosial untuk menunjang kesejahteraan masyarakat. Sebagai bagian adari upaya penanggulangan kejahatan, kebijakan pembaruan hukum pidana yang selanjutnya disebut Rancangan KUHP, adalah bagian dari memperbarui substansi hukum dalam rangka mengefektifkan penegakan hukum.

Adapun alasan-alasan yang mendasari perlunya pembaharuan hukum pidana nasional pernah diungkapkan oleh Sudarto, yaitu :

a. Alasan yang bersifat politik

Adalah wajar bahwa negara Republik Indonesia yang merdeka memiliki KUHP yang bersifat nasional, yang dihasilkan sendiri. Ini merupakan kebanggaan nasional yang inherent dengan kedudukan sebagai negara yang telah melepaskan diri dari penjajahan. Oleh karena itu, tugas dari pembentuk undang-undang adalah menasionalkan semua peraturan perundang-undangan warisan kolonial, dan ini harus didasarkan kepada Pancasila sebagai sumber dari segala sumber hukum.

b. Alasan yang bersifat sosiologis

Suatu KUHP pada dasarnya adalah pencerminan dari nilai-nilai kebudayaan dari suatu bangsa, karena ia memuat perbuatanperbuatan yang tidak dikehendaki dan mengikatkan pada perbuatanperbuatan itu suatu sanksi yang 
bersifat negatif berupa pidana. Ukuran untuk menentukan perbuatan mana yang dilarang itu tentunya tergantung pada pandangan kolektif yang terdapat dalam masyarakat tentang apa yang baik, yang benar dan sebaliknya.

c. Alasan yang bersifat praktis

Teks resmi WvS adalah berbahasa Belanda meskipun menurut Undang-Undang Nomor 1 Tahun 1946 dapat disebut secara resmi sebagai KUHP. Dapat diperhatikan bahwa jumlah penegak hukum yang memahami bahasa asing semakin sedikit. Di lain pihak, terdapat berbagai ragam terjemahan KUHP yang beredar. Sehingga dapat dimungkinkan akan terjadi penafsiran yang menyimpang dari teks aslinya yang disebabkan karena terjemahan yang kurang tepat.

KUHP nasional di masa mendatang harus dapat menyesuaikan diri dengan perkembanganperkembangan baru, khususnya perkembangan internasional yang sudah disepakati oleh masyarakat beradab.

Pembaharuan hukum pidana meliputi pembaharuan dalam bidang struktur, kultur dan materi hukum. Di samping itu, tidak ada artinya hukum pidana (KUHP) diganti/diperbaharui, apabila tidak dipersiapkan atau tidak disertai dengan perubahan ilmu hukum pidananya.

Dengan kata lain criminal law reform atau legal substance reform harus disertai pula dengan pembaharuan ilmu pengetahuan tentang hukum pidananya (legal/criminal science reform). Bahkan harus disertai pula dengan pembaharuan budaya hukum masyarakat (legal culture reform) dan pembaharuan struktur atau perangkat hukumnya (legal structure reform).
Sedangkan menurut Sudarto, pembaharuan hukum pidana yang menyeluruh itu harus meliputi pembaharuan hukum pidana material, hukum pidana formal dan hukum pelaksanaan pidana.

Dengan demikian pembaharuan KUHP hanya berarti pembaharuan KUHP (materi hukum pidana) dapat dilakukan dengan dua cara. Pertama, pembaharuan dengan cara parsial, yakni dengan cara mengganti bagian demi bagian dari kodifikasi hukum pidana. Dan kedua, pembaharuan dengan cara universal, total atau menyeluruh, yaitu pembaharuan dengan mengganti total kodifikasi hukum pidana

Dalam

penanggulangan kejahatan perlu ditempuh dengan pendekatan kebijakan yang integral, dalam arti : Ada keterpaduan (integralitas) antara politik kriminal dan politik sosial; Ada keterpaduan (integralitas) antar penanggulangan kejahatan dengan sarana "penal" tentu saja dilakukan melalui serangkaian kebijakan hukum pidana (penal policy). Dengan demikian usaha dan kebijakan untuk membuat hukum pidana yang baik dan berdayaguna atau politik hukum pidana (penal policy) merupakan bagian dari politik kriminal (criminal policy) sebagaimana telah diuraikan panjang lebar di atas.

Penanggulangan delik agama Pasal 156, Pasal 156 a dan UU Pnps No 1 Tahun 1965 belum menanggulangi delik agama. Kebijakan criminal baik penal maupun non penal memang

Pencegahan dan penanggulangan kejahatan dengan sarana penal memiliki beberapa tahap:

1. Formulasi (Kebijakan Legislatif)

2. Aplikasi (Kebijakan Yudikatif atau peradilan)

3. Eksekusi (Kebijakan EKsekutif) 
Pada tahap kebijakan legislatif ditetapkan sistem pemidanaan merupakan kewenangan menjatuhkan pidana. Dalam arti sempit, penjatuhan pidana berarti kewenangan mengenakan sanksi pidana menurut undang-undang oleh pejabat yang berwenang (HAKIM). Dalam arti luas, penjatuhan pidana merupakan mata rantai proses tindakan hukum dari pejabat yang berwenang mulai dari proses penyidikan, penuntutan sampai putusan pidana dijatuhkan oleh pengadilan dan dilaksanakan aparat pelaksana pidana. Maka kewenangan penyidkan pada hakikatnya merupakan bagian juga dari kewenangan pemidanaan.

Tidak hanya KUHP, KUHAP juga merupakan undang-undang diluar KUHP sebagai pelaksana pidana.

Perlu tidaknya pembaruan hukum pidana terletak pada seberapa jauh pelaksanaan mencapai tujuan itu tanpa paksaan dan pertimbangan antara nilai dari hasil dan nilai-nilai dari batasbatas kebebasan pribadi masing-masing.

1. Regulasi hak asasi manusia yang terdapat dalam UndangUndang Dasar 1945 hasil amandemen sudah tepat dan selaras dengan Universal Declaration Of Human Right. Di dalam KUHP ada pasal-pasal yang bermaksud melindungi kehidupan, kebebasan dan keamanan seseorang (antara lain, pasal-pasal mengenai pembunuhan, perampasan kemerdekaan, perampasan dan pengancaman, penculikan dan sebagainya; vide Pasal-Pasal 338-340, 333-334, 368-369, 328).

Ketentuan-ketentuan demikian identik dengan Pasal 3 UDHR. Juga di dalam KUHP ada larangan untuk perdagangan budak (Pasal 324-327) yang diidentik dengan Pasal 4 UDHR, dan ada pula larangan memeras/memaksa pengakuan atau keterangan dari seseorang dengan menggunakan sarana paksaan (Pasal 422) dan pasal-pasal penganiayaan (351, dst.) yang dapat diselaraskan dengan Pasal 5 UDHR.

Delik-delik terhadap harta benda dan pencabutan hak hanya berdasarkan undang-undang, identik dengan Pasal 17 UDHR. UU No. 39 Tahun 1999 memandatkan terbentuknya Pengadilan HAM yang memiliki jurisdiksi pengadilan Pelanggaran HAM yang berat paling lambat 4 (empat) tahun Undang-Undang Nomor 26 Tahun 2000 terbentuk.

Pengaturan tentang pengadilan HAM dalam UU No. 26 Tahun 2000 yang mempunyai jurisdiksi atas kejahatan genosida dan kejahatan terhadap kemanusiaan meskipun terhadap berbagai kelemahan tampaknya berupaya memenuhi ketentuan hukum internasional. Dalam undang-undang tersebut diciptakan suatu sistem pengadilan yang akan memastikan adanya proses pengadilan untuk penuntutan pelaku dan pemberian mekanisme reparasi korban.

Penuntasan kasus pelanggaran HAM yang menjadi tanggung jawab negara merupakan hal yang paling penting bagi korban dan keluarga korban pelanggaran HAM. Pembangunan demokrasi Indonesia ke depan tidak akan utuh selama penuntasan kasus-kasus pelanggaran HAM masih terbengkalai. Penuntasan kasus pelanggaran HAM masa lalu, bukan hanya untuk memberikan keadilan bagi korban dan keluarga korban pelanggaran HAM saja. Namun penuntasan kasus pelanggaran HAM akan memberikan efek jera kepada para pelaku pelanggar HAM, sehingga di kemudian hari tidak terjadi lagi kasuskasus pelanggaran HAM yang serupa. Artinya penuntasan kasus pelanggaran HAM akan memberikan jaminan 
keamanan bagi seluruh rakyat Indonesia dari tindakan-tindakan yang dapat menyebabkan pelanggaran HAM. Jikalau kasus-kasus pelanggaran HAM masa lalu dibiarkan, maka pelanggaran HAM akan berlanjut dan menimbulkan korban-korban baru.

Membangun hukum pidana Indonesia berarti membangun sistem hukum (pidana) di Indonesia, yang berarti meliputi pembangunan substansi hukum pidana (materiil dan formil), struktur hukum (official criminal justice system/aparat penegak hukum), dan kultur hukum. Pembangunan substansi hukum - tanpa bermaksud mengurangi peran bidang lainnya - merupakan kegiatan yang sangat penting dan fundamental, apalagi dalam bidang hukum pidana yang memiliki karakteristik keras (sering dikatakan "kejam") dibandingkan dengan bidang hukum lainnya. Oleh karena itu dalam pembangunan hukum pidana Indonesia harus memperhatikan seluruh aspek, yaitu idiologi (Pancasila), agama, sosial, politik, ekonomi, budaya yang hidup dan berkembang di masyarakat. Bahkan tidak boleh pula mengabaikan perkembangan internasional, karena negara Indonesia adalah menjadi bagian dari komunitas internasional yang beradap.

\section{SIMPULAN}

Hubungan kebijakan dari hukum pidana dengan kebijakan kriminal adalah upaya penanggulangan kejahatan dalam masyarakat dengan menggunakan hukum pidana.

\section{DAFTAR PUSTAKA}

\section{A Buku:}

Anwar, H.A.K. Moch., Hukum Pidana di Bidang Ekonomi, Bandung: Citra Aditya Bakti, 2000.

Arif, Barda Nawawi, Bunga Rampai Kebijakan Hukum Pidana, Citra Aditya Bakti, Bandung, 2002.

Muladi dan Arief Barda Nawawi, TeoriTeori dan Kebijakan Pidana, Alumni, Bandung, 1998.

Saleh, Roeslan, Pikiran-pikiran tentang Pertanggungjawbaan Pidana, The Habibie Center, Jakarta, 2002.

Sunarya, Sidik, Kapita Selekta Sistem Peradilan Pidana, Universitas Mohammadiyah, Malang, 2004.

\section{B Perundang-undangan:}

Kitab Undang-Undang Hukum Pidana (KUHP)

\section{INTERNET}

http://semuamakalahpembelajaran. blogspot.com/2018/04/makalahkebijakan-hukum-pidana.html

Silalahi, R. (2019). KAJIAN HUKUM ATAS PERNYELESAIAN PERSELISIHAN HUBUNGAN INDUSTRIAL SECARA KONSILIASI. Jurnal Darma Agung, 27(2), 1000-1011. Retrieved from https://jurnal.darmaagung.ac.id/index.p hp/jurnaluda/article/view/276 